\title{
IMPLEMENTASI STRATEGI PEMBELAJARAN SCAFFOLDING MELALUI LESSON STUDY PADA MATA KULIAH ANALISIS REAL
}

\author{
Nur Wahidin Ashari' ${ }^{1}$, Salwah $^{2}$, Fitriani $\mathbf{A}^{3}$ \\ ${ }^{1}$ Universitas Cokroaminoto, arhie_bilingual@yahoo.co.id \\ ${ }^{2}$ Universitas Cokroaminoto, salwa_gama@yahoo.com \\ ${ }^{3}$ Universitas Cokroaminoto, fitrianhy77@yahoo.com
}

\begin{abstract}
ABSTRAK
Jenis penelitian ini adalah penelitian deskriptif. Subyek dalam penelitian ini adalah mahasiswa semester VII tahun akademik 2015-2016. Penelitian ini menerapkan strategi pembelajaran scaffolding melalui lesson study pada materi analisis real, yang diselenggarakan pada bulan September hingga Oktober 2015. Strategi pembelajaran scaffolding yaitu mahasiswa diberi teorema-teorema, sulit tetapi sistematik dan selanjutnya siswa diberi bantuan untuk menyelesaikannya. Hasil dari penelitian ini menemukan bahwa (i) aktivitas pembelajaran mahasiswa dengan menggunakan strategi pembelajaran scaffolding melalui lesson study pada mata kuliah analisis real setiap siklusnya semakin meningkat. (ii) kemampuan mahasiswa dalam membuktikan teorema-teorema pada mata kuliah analisis real mengalami perkembangan mulai dari siklus pertama hingga siklus keempat. Awalnya mahasiswa dalam membuktikan teorema perlu bantuan dosen terus-menerus namun diakhir siklus, mahasiswa menjadi lebih mandiri dalam membuktikan teorema-teorema. (iii) kepercayaan diri dan keaktifan mahasiswa pun mengalami perubahan. Mahasiswa menjadi lebih percaya diri saat ditunjuk oleh dosen mengerjakan di papan tulis.
\end{abstract}

Kata Kunci: Scaffolding, Lesson study, Analisis Real.

\section{ABSTRACT}

The type of this research is a descriptive. Subjects in this study were students on VII semester of academic year 2015-2016. This research implement scaffolding learning strategy through lesson study in real analysis subject matter, which was held in September and October 2015. The scaffolding learning strategies present the theorems to the students, difficult but systematic and thereafter students are given assistance to complete. Results of the study are (i) the learning activities of students using scaffolding learning strategies through lesson study on the analysis of real subjects each cycle are increase. (ii) the ability of students to prove theorems in real analysis are increase for each cycles. Originally a student in proving the theorem need help lecturers constantly but at the end of the cycle, the students become more independent in proving theorems. (iii) the confidence and activity of the students are increase to. Students become more confident when appointed by lecturers working on the white board.

Keywords: Scaffolding, Lesson study, Analisis Real.

How to Cite: Ashari, N. W., Salwah, \& Fitriani, A. (2016). Scaffolding Melalui Lesson Study pada Mata Kuliah Analisis Real. Mathline: Jurnal Matematika dan Pendidikan Matematika, Vol.1, No.1, 23-36. 


\section{PENDAHULUAN}

Selama pendidikan masih ada, maka selama itu pula masalah-masalah tentang pendidikan akan selalu muncul dan orang pun tak akan henti-hentinya untuk terus membicarakan dan memperdebatkan tentang keberadaannya, mulai dari hal-hal yang bersifat fundamental-filsafiah sampai dengan hal-hal yang sifatnya teknis-operasional. Sebagian besar pembicaraan tentang pendidikan terutama tertuju pada bagaimana upaya untuk menemukan cara yang terbaik guna mencapai pendidikan yang bermutu dalam rangka menciptakan sumber daya manusia yang handal, baik dalam bidang akademis, sosio-personal, maupun vokasional (Purwati \& Supandi, 2012).

Profesionalisme dosen sangat diperlukan di universitas untuk keberhasilan pembelajaran dan peningkatan mutu pendidikan, tanpa profesionalisme, mutu pembelajaran tetap berjalan ditempat. Melalui Lesson Study sangat dibutuhkan kualifikasi, kinerja, dan kompetensi yang dimiliki oleh dosen professional untuk menuangkan buah pikirannya guna melaksanakan tugasnya sehari-hari (Juwairiah, 2012). Melalui dosen yang professional tersebut akan tercipta guru-guru yang berkualitas dan berkompeten dibidangnya, yang juga akan melahirkan insan-insan muda, generasi penerus bangsa.

Lesson study telah dipraktekan secara tekun dan terus menerus di Jepang sejak seabad lalu sebagai usaha peningkatan mutu pendidikan. lesson study sudah menjadi budaya sekolah-sekolah jepang terutama pada tingkat pendidikan dasar sehingga mutu pendidikan merata di Jepang, baik di kota maupun di desa. Peningkatan mutu pendidikan meningkatkan SDM (Sumber Daya Manusia) yang bermutu dan berakibat terhadap kemajuan bangsa jepang walaupun mereka tidak memiliki SDA (Sumber Daya Alam) yang banyak.

Lesson study adalah model pembinaan (pelatihan) profesi pendidik melalui pengkajian pembelajaran secara kolaboratif dan berkelanjutan berlandaskan prinsifprinsif kolegalitas dan mutual learning untuk membangun komunnitas belajar. Melalui komunitas belajar, guru/dosen saling belajar, berbagi pengalaman dan ide inovatif serta saling koreksi yang bermuara pada peningkatan mutu pendidikan secara terus menerus. Jika seorang dosen ingin meningkatkan pembelajaran maka salah satu cara yang paling jelas adalah melakukan kolaborasi dengan dosen lain untuk merancang, mengamati dan melakukan refleksi terhadap pembelajaran yang dilakukan. 
Menurut Juandi (2006), calon guru harus mempunyai dan memperoleh bekal yang cukup dalam daya matematik (mathematical power), baik dari segi materi (contens standards), kecakapan matematik (mathematical ability), maupun dalam kemampuan proses (standards process). Tugas paling penting dari dosen di program studi pendidikan matematika adalah memindahkan mahasiswa dari pemahaman matematika prosedural/komputasional kepada pemahaman luas yang mencakup menalar logis, generalisasi, abstraksi dan pembuktian formal.

Salah satu mata kuliah yang diwajibkan bagi calon guru matematika adalah analisis real. Hampir semua dosen matematika berpandangan bahwa, mengajarkan mata kuliah analisis real adalah hal yang paling sulit, dikarenakan mata kuliah tersebut memerlukan daya matematik (mathematical power), dan materi (contens standards) yang sangat tinggi. Mata kuliah analisis real membutuhkan pemahaman luas, penalaran logis, penalaran generalisasi, abstraksi dan pembuktian teorema-teorema yang sangat banyak dan sulit. Mengajarkan analisis real, tidak bisa langsung melepas mahasiswa begitu saja untuk menyelesaikan atau membuktikan teorema yang ada. Mahasiswa membutuhkan banyak bantuan dari dosen. Oleh karena itu, dosen perlu memikirkan cara, bagaimana agara mahasiswa dapat memahami materi-materi yang diajarkan dalam mata kuliah analisis real.

Strategi pembelajaran scaffolding melalui lesson study dapat dijadikan salah satu alternatif untuk mencapai daya matematik mahasiswa pada mata kuliah analisis real. Scaffolding berarti memberikan kepada individu sejumlah besar bantuan selama bertahap-tahap awal pembelajaran dan kemudian mengurangi bantuan tersebut dan memberikan kesempatan kepada anak didik tersebut untuk mengambil alih tanggung jawab yang semakin besar, segera setelah mampu mengerjakan sendiri (Mamin, 2008).

Bantuan yang diberikan oleh pembelajar (dosen) dapat berupa petunjuk, peringatan, dorongan, menguraikan masalah ke dalam bentuk lain yang memungkinkan siswa dapat mandiri. Scaffolding (mediated learning) yaitu siswa seharusnya diberi tugas-tugas kompleks, sulit tetapi sistematik dan selanjutnya siswa diberi bantuan untuk menyelesaikannya. Hal ini sangat sesuai dan sejalan dengan tujuan yang ingin dicapai pada mata kuliah analisis real.

Menurut Hogan dan Pressley (Lagne, 2002) terdapat lima teknik pembelajaran scaffolding, yaitu : 
1. Pemberian model perilaku yang diharapkan

2. Pemberian penjelasan

3. Mengundang siswa berpartisipasi

4. Menjelaskan dan mengklarifikasi pemahaman siswa

5. Mengundang siswa untuk mengemukakan pendapat.

Sedangkang Vygotsky mengidentifikasi empat tahap pembelajaran scaffolding Byrnes (Lagne, 2002) yaitu:

1. Tahap pertama adalah pemodelan, dengan penjelasan verbal.

2. Tahap kedua adalah peniruan siswa dari keterampilan yang telah mereka lihat atau dimodelkan oleh guru mereka, termasuk penjelasan. Selama fase ini, guru harus terus-menerus menilai pemahaman siswa dan sering menawarkan bantuan dan umpan balik.

3. Tahap ketiga adalah periode ketika instruktur mulai menghapus bimbingannya atau scaffolding-nya. Guru mengurangi untuk menawarkan bantuan dan umpan balik kepada murid-muridnya ketika murid - murid mereka mulai menguasai konten.

4. Pada tahap empat, para siswa telah mencapai tingkat ahli penguasaan. Mereka dapat melakukan tugas baru tanpa bantuan dari guru mereka.

Secara operasional (Syamsiah, 2008), strategi pembelajaran scaffolding dapat ditempuh melalui tahapan-tahapan berikut:

1. Mengecek hasil belajar sebelumnya

a) Assesmen keterampilan atau pengetahuan sebelumnya yang dimiliki oleh siswa berkaitan dengan tugas belajar baru yang akan diberikan. Assesmen hendaknya dilakukan secara perseorangan melalui interaksi langsung dengan masingmasing siswa.

b) Menentukan the Zone of Proximal Development (ZPD) untuk masing-masing siswa. Siswa kemudian dapat dikelompokkan menurut level perkembangan awal yang dimiliki dan atau yang membutuhkan ZPD yang relatif sama. Siswa dengan ZPD yang jauh berbeda dengan kemajuan rata-rata kelas dapat diberi perhatian khusus. 
2. Merancang tugas-tugas belajar (aktivitas belajar scaffolding)

a) Menjabarkan tugas pemecahan masalah ke dalam tahap-tahap yang rinci sehingga dapat membantu siswa melihat sasaran tugas yang diharapkan akan mereka lakukan.

b) Menyajikan tugas belajar secara berjenjang sesuai taraf perkembangan siswa. Ini dapat dilakukan dengan berbagai cara seperti melalui penjelasan, peringatan, dorongan (motivasi), penguraian masalah ke dalam langkah pemecahan dan pemberian contoh.

3. Memantau dan memediasi aktifitas dalam belajar

a) Mendorong siswa untuk bekerja dan belajar diikuti dengan pemberian dukungan seperlunya. Kemudian secara bertahap guru mengurangi dukungan langsungnya dan membiarkan siswa menyelesaikan tugas belajar secara mandiri.

b) Memberikan dukungan kepada siswa dalam bentuk pemberian isyarat, kata kunci, dorongan, contoh, atau hal lain yang dapat memancing siswa bergerak ke arah kemandirian belajar dan pengarahan diri.

4. Mengecek dan mengevaluasi belajar

a) Hasil belajar yang dicapai, bagaimana kemajuan belajar setiap siswa.

Proses belajar yang digunakan, apakah siswa bergerak ke arah kemandirian dan pengaturan diri dalam belajar.

Melalui Lesson Study di mana dosen model berkolaborasi dengan dosen lain mulai dari perencanaan pembelajaran, pelaksanaan hingga refleksi, sehingga diharapkan pembelajaran mata kuliah analisis real dapat berjalan baik dan sesuai dengan yang diharapkan.

Lesson Study (LS) pada awalnya dimulai dengan pengkajian materi kurikulum (kyouzai kenkyuu) yang berfokus pada pengajaran matematika bagi guru-guru di Jepang untuk menguji keefektifan pengajarannya dalam rangka meningkatkan hasil pembelajaran. Kajian tersebut mendasarkan diri pada kurikulum matematika di U.S yang dirancang berbasis temuan-temuan penelitian unggul. Kajian tersebut melahirkan suatu perubahan paradigma tentang materi kurikulum dari "memanjakan" menuju pada "pemberdayaan" potensi siswa (Purwati \& Supandi, 2012). 
Apabila kita cermati definisi lesson study maka kita menemukan 7 kata kunci yaitu pembinaan profesi, pengkajian pembelajaran, kolaboratiif, berkelanjutan, kolegalitas, mutual learning, dan komunitas belajar. lesson study bertujuan untuk melakukan pembinaan profesi pendidik secara berkelanjutan agar terjadi peningkatan profesionalitas pendidik terus-menerus.

Lesson study dilaksanakan dalam tiga tahapan yaitu plan (merencanakan), do (melaksanakan) dan see (merefleksi) yang berkelanjutan yang ditunjukkan pada Gambar 1. Dengan kata lain lesson study merupakan suatu cara peningkatan mutu pendidikan yang tak pernah berakhir (continous improvement).

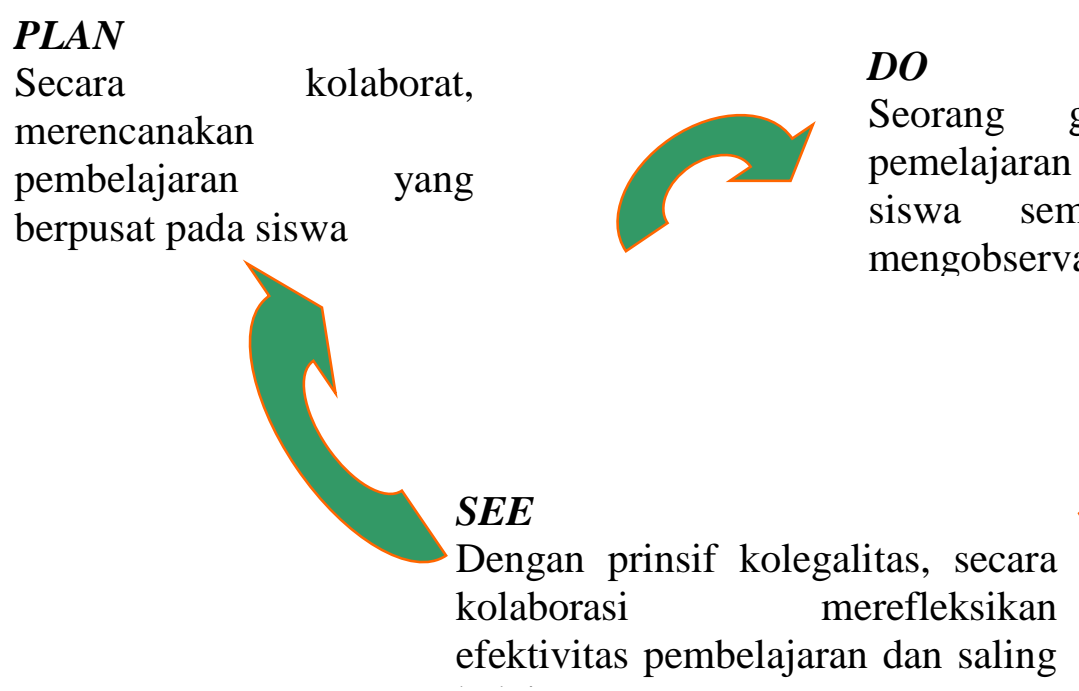

Gambar 1. Siklus Kajian Pembelajaran dalam Lesson Study

Berdasarkan latar belakang di atas, maka dirumuskan masalah sebagai berikut:

1. Bagaimana aktivitas pembelajaran mahasiswa pada mata kuliah analisis real?

2. Bagaimana kemampuan mahasiswa membuktikan teorema-teorema pada mata kuliah analisis real?

Berdasarkan latar belakang dan rumusan masalah di atas, maka tujuan penelitian ini adalah untuk mengetahui:

1. Aktivitas pembelajaran mahasiswa pada mata kuliah analisis real.

2. Kemampuan mahasiswa dalam membuktikan teorema-teorema pada mata kuliah analisis real. 


\section{METODE PENELITIAN}

\section{Jenis Kegiatan}

Kegiatan lesson study merupakan kegiatan untuk meningkatkan kualitas mahasiswa dan menciptakan dosen profesional. Kegiatan ini dilakukan sebanyak empat siklus selama satu semester. Setiap siklus terdiri atas perencanaan (plan), observasi (do), dan refleksi (see). Subjek pada kegiatan lesson study ini adalah mahasiswa semester VII kelas VII.B dan VII.D Program Studi Pendidikan Matematika Universitas Cokroaminoto Palopo tahun akademik 2015/2016.

\section{Tempat dan Waktu Kegiatan}

Kegiatan Lesson Study ini bertempat di Kampus III Universitas Cokroaminoto Palopo Program Studi Pendidikan Matematika yang disetting sebagai kelas perkuliahan Mata Kuliah Analisis Real. Adapun waktu kegiatan pelaksanaan Lesson Study berlangsung selama 2 bulan yang terdiri dari 4 siklus kegiatan, di mana masing-masing siklus dilaksanakan dengan tahapan Plan, Do dan See. Waktu kegiatan Lesson Study terlihat pada tabel berikut.

Tabel 1. Waktu kegiatan Lesson Study

\begin{tabular}{|c|c|c|c|c|c|c|c|}
\hline Siklus & \multicolumn{3}{|c|}{ Plan } & \multicolumn{2}{|c|}{ Do } & \multicolumn{2}{|c|}{ See } \\
\hline I & $\begin{array}{l}\text { Senin, } \\
2015\end{array}$ & 14 & September & $\begin{array}{l}\text { Rabu, } \\
2015\end{array}$ & September & $\begin{array}{l}\text { Rabu, } \\
2015\end{array}$ & September \\
\hline II & $\begin{array}{l}\text { Kamis, } \\
2015\end{array}$ & 17 & September & $\begin{array}{ll}\text { Kamis, } & 17 \\
2015 & \end{array}$ & September & $\begin{array}{l}\text { Jumat, } \\
2015\end{array}$ & September \\
\hline III & $\begin{array}{l}\text { Senin, } \\
2015\end{array}$ & 28 & September & $\begin{array}{l}\text { Rabu, } 30 \\
2015\end{array}$ & September & $\begin{array}{l}\text { Rabu, } 30 \\
2015\end{array}$ & September \\
\hline IV & Kamis, & Okt & ber 2015 & Kamis, $1 \mathrm{Ol}$ & tober 2015 & Jumat, $2 \mathrm{Ok}$ & tober 2015 \\
\hline
\end{tabular}

\section{HASIL DAN PEMBAHASAN}

Pada bagian ini, akan dijelaskan gambaran pelaksanaan lesson study yang terdiri dari empat siklus. Setiap siklus akan menjelaskan tentang kegiatan perencanaan (plan), pelaksanaan (do) dan refleksi (see).Gambaran kegiatan lesson study setiap siklus dipaparkan sebagai berikut:

\section{Siklus Pertama Kegiatan Lesson Study}

\section{Tahapan Perencanaan (Plan)}

Tahap ini diawali dengan duduk bersama dan berdiskusi menyusun Rencana pembelajaran yaitu berupa bahan ajar/handout, LKM, serta rencana proses pembelajaran di kelas. Dosen secara kolaboratif berbagi ide menyusun rancangan 
pembelajaran untuk menghasilkan cara-cara pengorganisasian bahan ajar, proses pembelajaran, maupun penyiapan alat bantu pembelajaran. Sebelum diimplementasikan dalam kelas, rancangan pembelajaran yang telah disusun kemudian disimulasikan.

Tujuan yang ingin dicapai setelah menyelesaikan siklus ini adalah mahasiswa diharapkan dapat menyelesaikan masalah pembuktian yang berhubungan dengan himpunan dan fungsi. Bagi seorang dosen tahapan perencanaan ini penting dalam upayanya untuk memperbaiki dan/atau meningkatkan layanan pembelajaran secara lebih professional, dosen dituntut keberaniannya untuk mengatakan secara jujur khususnya kepada dirinya sendiri mengenai sisi - sisi lemah yang masih terdapat dalam implementasi program pembelajaran yang dikelolanya. Hasil diskusi bersama para observer pada tahapan plan ditunjukkan pada lampiran siklus 1.

\section{Tahapan Pelaksanaan (Do)}

Pada tahap awal, dosen membagi mahasiswa ke dalam kelompok-kelompok kecil yang terdiri dari 4-5 mahasiswa. Dosen memberikan apersepsi kepada siswa mengenai materi himpunan dan fungsi yaitu dengan menanyakan beberapa sifat-sifat himpunan beserta fungsi, guna mengingatkan kembali mahasiswa kedua materi tersebut. Pada tahap inti, dosen model memberikan LKM kepada setiap kelompok untuk mereka diskusikan, dan selanjutnya dosen memberikan bantuan secara bertahap pada setiap kelompok yang tidak memahami jalan atau proses penyelesaian dari masalah yang diberikan. Tahap terakhir (kegiatan penutup), dosen model memberikan evaluasi pemahaman dengan memberikan kesempatan kepada mahasiswa untuk mengungkapkan apa yang mereka pahami mengenai materi yang telah diberikan.

\section{Tahapan Refleksi (See)}

Tahap do yang telah dilaksanakan masih memiliki beberapa kekurangan. Oleh karena itu, peneliti merekomendasikan bahwa pada siklus II, tetap mempertahankan aktivitas yang telah membuat kemajuan atau perkembangan pada siklus I dan juga meningkatkan/memfokuskan tindakan-tindakan berikut ini:

a) Pengaturan tempat duduk kelompok sebaiknya diatur saat sebelum pembelajaran dimulai untuk lebih mengefisienkan waktu.

b) Pembentukan kelompok yang awalnya dibuat oleh mahasiswa itu sendiri sebaiknya diacak oleh dosen pengampu mata kuliah, sehingga lebih heterogen. 
c) Posisi tempat duduk kelompok sebaiknya ditukar, yang semula duduk di belakang ditukar ke depan. Agar mahasiswa yang duduknya di belakang tidak sibuk sendiri saat dosennya menjelaskan.

Bahan yang digunakan untuk refleksi adalah catatan yang dimiliki observer dan hasil rekaman tim dokumentasi yang dapat diputar ulang untuk kejadian yang menarik perhatian. Catatan-catatan tersebut digunakan sebagai pertimbangan dalam menyusun perencanaan perkuliahan berikutnya. Hasil diskusi bersama para observer pada tahapan see ditunjukkan pada lampiran siklus 1 .

\section{Siklus Kedua Kegiatan Lesson Study}

Dari hasil refleksi dapat diperoleh sejumlah pengetahuan baru atau keputusankeputusan penting guna perbaikan dan peningkatan proses pembelajaran selanjutnya. Siklus kedua ini mulai dilaksanakan pada hari Kamis, 17 September 2015, di tempat dan materi yang sama namun dengan tujuan perkuliahan yang berbeda. Tujuan perkuliahan yang ingin dicapai setelah menyelesaikan siklus II ini yaitu diharapkan mahasiswa mampu membuktikan teorema yang berhubungan dengan himpunan dan fungsi.

Tujuan diperkenalkannya mahasiswa dengan pembuktian teorema pada materi himpunan dan fungsi tidak lain untuk memperkenalkan mata kuliah analisis real yang kedepannya akan melakukan pembuktian-pembuktian teorema. Teorema-teorema awal ini diberikan agar mahasiswa dibiasakan untuk membuktikan.

\section{Tahap Perencanaan (Plan)}

Pada tahap ini, peneliti merancang pembelajaran yang didasarkan dari hasil refleksi pada siklus I. Rancangan pembelajaran yang telah didiskusikan dengan observer memiliki beberapa perbaikan yaitu khususnya pada pengelolaan kelas. Perbaikan ini diharapkan agar semua siswa dapat aktif dalam proses pembelajaran. Perincian hasil diskusi dapat dilihat pada lampiran siklus II.

\section{Tahap Pelaksanaan (Do)}

Pada tahapan inti, dosen memberikan penjelasan materi dan contoh pembuktian teorema kepada mahasiswa. Dosen juga memberikan bahan ajar beserta LKM kepada mahasiswa yang selanjutnya akan mereka diskusikan bersama teman kelompoknya. LKM tersebut berisi teorema-teorema yang harus dibuktikan oleh mahasiswa. 
Selanjutnya, mahasiswa mengerjakan teorema yang ada pada LKM, dosen memberikan bantuannya sedikit demi sedikit dan kemudian melepas mahasiswa untuk membuktikan dengan sendirinya. Setelah mahasiswa selesai mengerjakan LKM mereka, langkah terakhir (kegiatan penutup), dosen model memberikan kesempatan kepada kelompok yang telah ditunjuknya untuk mempresentasikan hasil pekerjaan mereka dan mengajukan beberapa pertanyaan untuk menetahui sejauh mana pemahaman mahasiswa tentang materi yang mereka kerjakan.

\section{Tahap Refleksi (See)}

Pada tahap see, tim pelaksana lesson study mendiskusikan semua hasil pengamatan yang telah dilaksanakan. Tahap do yang telah dilaksanakan masih memiliki beberapa kekurangan. Oleh karena itu, peneliti merekomendasikan bahwa pada siklus III, tetap mempertahankan aktivitas yang telah membuat kemajuan atau perkembangan pada siklus II dan juga meningkatkan/memfokuskan tindakan-tindakan berikut ini:

a) Terdapat posisi tempat duduk mahasiswa yang membelakangi dosen, oleh karenanya ada mahasiswa yang tidak memperhatikan penjelasan dosennya. Sebaiknya posisi mahasiswa dibentuk dalam posisi $U$ dan dirapatkan sehingga semua mahasiswa dapat terjangkau oleh dosen model.

b) Posisi tempat duduk kelompok sebaiknya ditukar, yang semula duduk di belakang ditukar ke depan. Agar mahasiswa yang duduknya di belakang tidak sibuk sendiri saat dosennya menjelaskan.

c) Dosen sebaiknya lebih sering mengontrol semua kelompok agar materi yang diajarkan dapat dipahami oleh semua mahasiswa.

Berdasarkan hasil diskusi tim pelaksana lesson study, maka perlu melakukan pembenahan dan perencanaan pembelajaran yang lebih matang untuk siklus III, agar pelaksanaan lesson study ini dapat berjalan dengan baik dan mampu mencapai tujuan yang telah direncanakan. Hasil diskusi bersama para observer pada tahapan see ditunjukkan pada lampiran siklus II.

\section{Siklus Ketiga Kegiatan Lesson Study}

Dari hasil refleksi dapat diperoleh sejumlah pengetahuan baru atau keputusankeputusan penting guna perbaikan dan peningkatan proses pembelajaran selanjutnya. Siklus ketiga ini mulai dilaksanakan pada hari Senin, 28 September 2015, di tempat yang sama namun pada materi yang berbeda. Materi yang diajarkan pada siklus ini 
adalah Sistem Bilangan Real. Materi ini merupakan awal dan foundamental (dasar) dari analisis real. Tujuan perkuliahan yang ingin dicapai setelah menyelesaikan siklus III ini yaitu diharapkan mahasiswa mampu membuktikan teorema dengan menggunakan aksioma lapangan.

\section{Tahap Perencanaan (Plan)}

Pada tahap ini, peneliti merancang pembelajaran yang didasarkan dari hasil refleksi pada siklus II. Rancangan pembelajaran yang telah didiskusikan dengan observer memiliki beberapa perbaikan yaitu khususnya pada pengelolaan kelas, bahan ajar, dan assessment (penilaian). Perbaikan ini diharapkan agar semua siswa dapat aktif dalam proses pembelajaran. Perincian hasil diskusi dapat dilihat pada lampiran siklus III.

\section{Tahap Pelaksanaan (Do)}

Pada tahapan inti, dosen mulai memberikan bahan ajar dan waktu sekitar 20 menit kepada mahasiswa untuk menghapalkan aksioma lapangan. Setelah mahasiswa selesai meghapalkan aksioma-aksioma tersebut, dosen menunjuk satu per satu mahasiswa dan mengecek hapalan mereka. Selanjutnya, dosen memberikan penjelasan materi dan contoh pembuktian teorema kepada mahasiswa. Langkah berikutnya, dosen memberikan LKM kepada mahasiswa yang kemudian mereka diskusikan bersama teman kelompoknya. LKM tersebut berisi teorema-teorema yang harus dibuktikan oleh mahasiswa.

Selanjutnya, mahasiswa mengerjakan teorema yang ada pada LKM, dosen memberikan bantuannya sedikit demi sedikit dan kemudian melepas mahasiswa untuk membuktikan dengan sendirinya. Setelah mahasiswa selesai mengerjakan LKM mereka, langkah terakhir (kegiatan penutup), dosen model memberikan kesempatan kepada kelompok yang telah ditunjuknya untuk mempresentasikan hasil pekerjaan mereka dan mengajukan beberapa pertanyaan untuk menetahui sejauh mana pemahaman mahasiswa tentang materi yang mereka kerjakan.

\section{Tahap Refleksi (See)}

Pada tahap see, tim pelaksana lesson study mendiskusikan semua hasil pengamatan yang telah dilaksanakan. Tahap do yang telah dilaksanakan masih memiliki beberapa kekurangan. Oleh karena itu, peneliti merekomendasikan bahwa pada siklus IV, tetap mempertahankan aktivitas yang telah membuat kemajuan atau perkembangan 
pada siklus II dan juga meningkatkan/memfokuskan tindakan berikut ini: "Mahasiswa masih malu bertanya kepada dosen. Sebaiknya dosen memberikan stimulus kepada mahasiswa sehingga mahasiswa lebih percaya diri”.

Berdasarkan hasil diskusi tim pelaksana lesson study, maka perlu melakukan pembenahan dan perencanaan pembelajaran yang lebih matang untuk siklus IV, agar pelaksanaan lesson study ini dapat berjalan dengan baik dan mampu mencapai tujuan yang telah direncanakan. Hasil diskusi bersama para observer pada tahapan see ditunjukkan pada lampiran siklus III.

\section{Siklus Keempat Kegiatan Lesson Study}

Dari hasil refleksi dapat diperoleh sejumlah pengetahuan baru atau keputusankeputusan penting guna perbaikan dan peningkatan proses pembelajaran selanjutnya. Tujuan perkuliahan yang ingin dicapai setelah menyelesaikan siklus IV ini yaitu diharapkan mahasiswa mampu membuktikan teorema yang berhubungan dengan aksioma lapangan.

\section{Tahap Perencanaan (Plan)}

Pada tahap ini, peneliti merancang pembelajaran yang didasarkan dari hasil refleksi pada siklus III. Rancangan pembelajaran yang telah didiskusikan dengan observer memiliki beberapa perbaikan yaitu khususnya pada strategi pembelajaran, dan bahan ajar. Perbaikan ini diharapkan agar semua siswa dapat aktif dalam proses pembelajaran. Perincian hasil diskusi dapat dilihat pada lampiran siklus IV.

\section{Tahap Pelaksanaan (Do)}

Kegiatan pembelajaran dimulai oleh dosen model dengan membuka dan menyampaikan tujuan pembelajaran yang akan dicapai. Dosen model mengajak mahasiswa untuk mengingat kembali sifat-sifat pada operasi biner pada mata kuliah stuktur aljabar dengan pertimbangan bahwa mata kuliah tersebut telah mereka dapatkan semester sebelumnya. Tujuannya agar mahasiswa dapat mengaitkan materi tersebut dengan aksioma lapangan yang mereka dapatkan saat itu.

Pada tahapan inti, dosen mulai memberikan bahan ajar dan waktu sekitar 20 menit kepada mahasiswa untuk menghapalkan aksioma lapangan. Setelah mahasiswa selesai meghapalkan aksioma-aksioma tersebut, dosen menunjuk satu per satu mahasiswa dan mengecek hapalan mereka. Berbeda dengan siklus ketiga, pada siklus ini dosen juga memberikan modifikasi soal yang berkaitan dengan aksioma lapangan. 
Beberapa mahasiswa menyebutkan jenis aksioma lapangan yang dimaksud jika ditunjuk oleh dosen.

Selanjutnya, dosen memberikan penjelasan materi dan contoh pembuktian teorema kepada mahasiswa. Langkah berikutnya, dosen memberikan LKM kepada mahasiswa yang kemudian mereka diskusikan bersama teman kelompoknya. LKM tersebut berisi teorema-teorema yang harus dibuktikan oleh mahasiswa.

Selanjutnya, mahasiswa mengerjakan teorema yang ada pada LKM, dosen memberikan bantuannya sedikit demi sedikit dan kemudian melepas mahasiswa untuk membuktikan dengan sendirinya. Setelah mahasiswa selesai mengerjakan LKM mereka, langkah terakhir (kegiatan penutup), dosen model memberikan kesempatan kepada kelompok yang telah ditunjuknya untuk mempresentasikan hasil pekerjaan mereka dan mengajukan beberapa pertanyaan untuk menetahui sejauh mana pemahaman mahasiswa tentang materi yang mereka kerjakan.

\section{Tahap Refleksi (See)}

Dalam tahap see ini, observer dan dosen model mengadakan refleksi dimana pokok-pokok hasil refleksi dapat dideskripsikan sebagai berikut:

a) Sebagian besar mahasiswa sudah lebih percaya diri ketika menjawab pertanyaan dosen di papan tulis.

b) Mahasiswa lebih aktif bekerja dalam kelompok.

c) Mahasiswa tidak bekerja secara individu lagi tetapi bekerjasama dengan teman kelompoknya.

d) Namun, mata kuliah analisis real tetap masih dianggap sulit oleh sebagian besar mahasiswa. Oleh karena itu, masih diperlukan model, teknik, pendekatan, dan strategi pembelajaran lain yang kiranya dapat membantu mahasiswa untuk lebih paham lagi dengan materi-materi pada mata kuliah analisis real.

\section{KESIMPULAN}

Berdasarkan pelaksanaan pembelajaran yang telah dilakukan, maka dapat disimpulkan bahwa:

1. Aktivitas pembelajaran mahasiswa dengan menggunakan strategi pembelajaran scaffolding melalui lesson study pada mata kuliah analisis real setiap siklusnya semakin meningkat. 
2. Kemampuan mahasiswa dalam membuktikan teorema-teorema pada mata kuliah analisis real mengalami perkembangan mulai dari siklus pertama hingga siklus keempat. Awalnya mahasiswa dalam membuktikan teorema perlu bantuan dosen terus-menerus namun diakhir siklus, mahasiswa menjadi lebih mandiri dalam membuktikan teorema-teorema.

3. Kepercayaan diri dan keaktifan mahasiswa pun mengalami perubahan. Mahasiswa menjadi lebih percaya diri saat ditunjuk oleh dosen mengerjakan di papan tulis.

\section{DAFTAR PUSTAKA}

Juandi, Dadang. (2006). Membantu Mahasiswa Calon Guru Matematika Mengembangkan Daya Matematiknya. Disertasi UPI: Tidak diterbitkan.

Juwairiah. (2012). Professionalisme Guru melalui Lesson Study. Tersedia di sumut.kemenag.go.id/file/file/.../akzh1343183231.pdf. Diakses November 2015.

Lange, Verna Leigh. 2002. Instructional Scaffolding. Prepared at http://condor.admin.ccny.cuny. Edu/ group4/Lange/lange\%20paper.doc. Agustus 2015.

Mamin. (2008). Penerapan Metode Pembelajaran Scaffolding Pada Pokok Bahasan Sistem Periodik Unsur. Jurnal Chemica Vol/. 10 Nomor 2 Desember 2008, 5560

Purwati \& Supandi. (2012). Meningkatkan Kompetensi dan Profesionalisme Dosen melalui Lesson Study. e-jurnal.upgrismg.ac.id/index.php/ aksioma/article/view/42.

Syamsiah, Sitti. 2008. Thesis Unpublished: Peningkatan Hasil Belajar Matematika Melalui Pembelajaran Kooperatif Dengan Mengintensifkan Scaffolding Di Kelas IX/H SMP Negeri 2 Takalar. Makassar: Universitas Negeri Makassar 